\title{
A NOTE ON SOME PHYSICAL CONDITIONS FOR CULTIVATING OXYRRHIS MARINA
}

\author{
By M. R. Droop \\ Marine Station, Millport, Scotland
}

(Text-figs. $\mathrm{I}-4$ )

This note concerns a series of experiments to determine the best conditions of salinity, temperature and $\mathrm{pH}$ for cultivating the euryhaline phagotrophic dinoflagellate Oxyrrhis marina Dujardin.

The strain of Oxyrrhis employed was isolated from a brackish pool at Tvärminne, Finland (Droop, I953 $a, b$ ). The culture medium for the experiments contained soil extract and an artificial sea water, SW I $(\mathrm{NaCl}$, $\mathrm{MgCl}_{2} 6 \mathrm{H}_{2} \mathrm{O}, \mathrm{KCl}$, and $\mathrm{CaSO}_{4} 2 \mathrm{H}_{2} \mathrm{O}$ in the proportions by weight $15: 2 \cdot 5$ : $0.4: 0.5$ ), and for food a small quantity of the yeast Saccharomyces exiguus was administered daily from an agar culture with a wire loop.

The rate of cell division during the logarithmic phase of growth is a measure of the suitability of conditions prevailing. Since growth is by binary fission the number of divisions per day is conveniently given by the relative growth rate when expressed as the binary logarithm of the relative increase in cell numbers per day. This parameter, denoted by $k$, is simply the slope of the growth curve when cell numbers are expressed as binary logarithms.

Cell counts were made in a deep chamber which allowed the whole of a O. I ml. sample to be counted if required. Five samples were usually counted but when numbers exceeded roo per sample it was more convenient to count several areas within the sample with the aid of a squared eyepiece graticule and compute accordingly.

The statistical treatment in the salinity experiments followed conventional procedures of regression analysis (Snedecor, 1946) and was carried out on the transformed counts. I am indebted to my colleague T. B. Bagenal for advice and for undertaking the analysis.

\section{SALINITY}

Different salinities were obtained by varying the amount of SW I in the medium. Cultures of Oxyrrhis can thrive if the salinity lies between $4 \%$ and I30\%. ${ }^{1}$ Greater salinities were not tested, but below $4 \%$ cultures failed.

The salinity experiments were required to determine the optimum salinity and also the effect of transfer from one salinity to another. They consisted of

\footnotetext{
$1 \%$, titrated chloride expressed as $\mathrm{g} \mathrm{NaCl}$ per 1 .
} 
two sets of cultures grown at room temperatures and initial $\mathrm{pH} 7 \cdot 4$ in the following salinities: $4,8,16,32$ and $64 \%$, from inocula adapted to $8 \%$ in the one set and $64 \%$ in the other. The parameters to be determined were, relative growth rate, 'apparent initial viable count', and 'initial total count'.

TABLE 1. GROWTH OF OXYRRHIS IN CULTURES OF DIFFERENT SALINITY AND INOCULA FROM TWO DIFFERENT SOURCES

(Counts expressed as $\log _{2}$ cells per ml. Those shown in italics lie off the logarithmic phase of growth and were not used in calculating the regression coefficients.)

\begin{tabular}{|c|c|c|c|c|c|c|c|c|c|c|}
\hline \multirow{2}{*}{$\begin{array}{l}\text { Culture } \\
\text { salinity }\end{array}$} & \multicolumn{5}{|c|}{ Inoculum from $8 \%$ culture } & \multicolumn{5}{|c|}{ Inoculum from $64 \%$ culture } \\
\hline & $4 \%$ & $8 \%$ & $16 \%$ & $32 \%$ & $64 \%$ & $4 \%$ & $8 \%$ & $16 \%$ & $32 \%$ & $64 \%$ \\
\hline 3 rd day & $\begin{array}{l}4 \cdot 9 \\
4 \cdot 32 \\
5 \cdot 32 \\
3 \cdot 32 \\
4 \cdot 9\end{array}$ & $\begin{array}{l}6 \cdot 75 \\
6 \cdot 58 \\
6 \cdot 58 \\
5 \cdot 58 \\
6 \cdot 75\end{array}$ & $\begin{array}{l}8 \cdot 4 \mathrm{I} \\
8 \cdot 45 \\
8 \cdot 49 \\
8 \cdot 64 \\
8 \cdot \mathrm{I} 2\end{array}$ & $\begin{array}{l}5.32 \\
5.64 \\
6.32 \\
6 \cdot 13 \\
4.32\end{array}$ & $\begin{array}{l}\bar{Z} \\
\bar{Z}\end{array}$ & $\begin{array}{l}6 \cdot 64 \\
7 \cdot 90 \\
7 \cdot 84 \\
7 \cdot 02 \\
7 \cdot 49\end{array}$ & $\begin{array}{l}8.99 \\
9.09 \\
8.87 \\
9.60 \\
6.27\end{array}$ & $\begin{array}{r}10.00 \\
\text { 10.57 } \\
\text { 10.26 } \\
9.64 \\
9.22\end{array}$ & & $\begin{array}{l}8.02 \\
7.96 \\
7.13 \\
7.71 \\
7.64\end{array}$ \\
\hline 5 th day & $\begin{array}{l}6 \cdot 13 \\
5 \cdot 90 \\
6 \cdot 49 \\
6 \cdot 13 \\
6 \cdot 32\end{array}$ & $\begin{array}{l}9 \cdot 46 \\
9 \cdot 70 \\
9 \cdot 66 \\
9 \cdot 45 \\
9 \cdot 71\end{array}$ & $\begin{array}{l}\text { I } 2 \cdot 84 \\
\text { I2 } 23 \\
\text { I2 } \cdot 02 \\
\text { II } \cdot 32 \\
\text { II } \cdot 49\end{array}$ & $\begin{array}{l}9 \cdot 86 \\
9 \cdot 88 \\
9 \cdot 80 \\
9 \cdot 94 \\
9 \cdot 88\end{array}$ & $\begin{array}{l}- \\
4 \cdot 32 \\
4 \cdot 32 \\
3 \cdot 32 \\
3 \cdot 32\end{array}$ & $\begin{array}{l}8 \cdot 36 \\
8 \cdot 45 \\
8 \cdot 32 \\
8 \cdot 22 \\
8 \cdot 17\end{array}$ & & & & $\begin{array}{r}9 \cdot 10 \\
\text { 10.07 } \\
9 \cdot 34 \\
9 \cdot 45 \\
9.34\end{array}$ \\
\hline 7 th day & $\begin{array}{l}5.90 \\
5.64 \\
6.49 \\
6.64 \\
6.9\end{array}$ & $\begin{array}{l}12.57 \\
12.82 \\
13.11 \\
13 \cdot 12 \\
12.78\end{array}$ & $\begin{array}{l}16 \cdot 52 \\
16 \cdot 48 \\
16 \cdot 63 \\
16 \cdot 22 \\
16 \cdot 71\end{array}$ & & & $\begin{array}{l}8 \cdot 4 I \\
8 \cdot I 2 \\
7 \cdot 96 \\
8 \cdot 07 \\
7 \cdot 64\end{array}$ & & & & $\begin{array}{r}\text { IO.14 } \\
\text { IO.54 } \\
9.64 \\
\text { IO.26 } \\
\text { 10.38 }\end{array}$ \\
\hline Ioth day & $\begin{array}{l}6.79 \\
7 \cdot 13 \\
5.32 \\
6 \cdot 91 \\
7 \cdot 23\end{array}$ & $\begin{array}{l}15.32 \\
15.46 \\
15.80 \\
15.52 \\
15.52\end{array}$ & $\begin{array}{l}16 \cdot 28 \\
16 \cdot 28 \\
16 \cdot 68 \\
16 \cdot 86 \\
16 \cdot 52\end{array}$ & $\begin{array}{r}15.16 \\
15.58 \\
15.75 \\
15.58 \\
15.64\end{array}$ & $\begin{array}{l}-8 \cdot 18 \\
8 \cdot 23 \\
6.49 \\
-\end{array}$ & $\begin{array}{l}\bar{Z} \\
\overline{-}\end{array}$ & $\begin{array}{l}14.96 \\
14.70 \\
15.00 \\
15.09 \\
15.25\end{array}$ & $\begin{array}{l}15.94 \\
16.92 \\
15.83 \\
15.96 \\
15.49\end{array}$ & $\begin{array}{l}15.12 \\
15.64 \\
15.12 \\
15.64 \\
15.78\end{array}$ & $\begin{array}{l}\text { I2.52 } \\
\text { I2.21 } \\
12.32 \\
13.21 \\
12.75\end{array}$ \\
\hline I2th day & $\begin{array}{l}\bar{z} \\
\bar{z}\end{array}$ & $\begin{array}{l}16.52 \\
16.64 \\
16.55 \\
16 \cdot 46 \\
16.35\end{array}$ & $\begin{array}{l}\bar{z} \\
\bar{z}\end{array}$ & $\begin{array}{l}16.52 \\
16.04 \\
16.20 \\
16.58 \\
16.24\end{array}$ & $\begin{array}{l}-\overline{10} \\
10.85 \\
10.81 \\
10.93 \\
-\end{array}$ & $\begin{array}{l}E \\
- \\
-\end{array}$ & $\begin{array}{l}\bar{Z} \\
\bar{z}\end{array}$ & $\begin{array}{l}\bar{Z} \\
\bar{Z}\end{array}$ & $\begin{array}{l}= \\
\bar{Z}\end{array}$ & $\begin{array}{l}z \\
z\end{array}$ \\
\hline I4th day & $\begin{array}{l}\bar{z} \\
\bar{z}\end{array}$ & $\begin{array}{l}\bar{z} \\
\bar{z}\end{array}$ & $\begin{array}{l}\bar{z} \\
\bar{z}\end{array}$ & $\begin{array}{l}- \\
-\end{array}$ & $\begin{array}{l}\mathrm{I} 2 \cdot 32 \\
\mathrm{I} 2 \cdot 13 \\
\mathrm{I} 2 \cdot 77 \\
\mathrm{II} \cdot 09 \\
\mathrm{II} \cdot 09\end{array}$ & $\begin{array}{l}\bar{z} \\
\bar{z}\end{array}$ & $\begin{array}{l}\bar{z} \\
\bar{z}\end{array}$ & $\begin{array}{l}\bar{z} \\
\bar{z}\end{array}$ & $\begin{array}{l}E \\
z\end{array}$ & $\begin{array}{l}z \\
z\end{array}$ \\
\hline
\end{tabular}

The ten growth curves are shown in Table I. The earlier counts of each cover the logarithmic phase of growth, and are, therefore, fitted statistically by the general equation

$$
n=k t+c,
$$

when $n$ represents $\log _{2}$ cells per ml. at time $t, k$ and $c$ being constants, the former the relative growth rate, the latter the logarithm of the 'apparent initial viable count', i.e. $n$ at $t=0$. The two constants and their $95 \%$ fiducial limits for the ten regressions are plotted against salinity in Figs. I and 2. 
Since a clear maximum for $k$ occurred at $16 \%$ in both experiments (Fig. I) it can be concluded that the optimum salinity at $16 \%$ was not influenced by the salinity of the inoculum.

In contrast to $k$, the second constant $c$ did depend to some extent on the source of the inoculum. The value of $c$ must be determined primarily by the 'initial total count', that is the number of cells introduced, but it would be influenced either by mortality of cells on transfer or by an initial lag preceding the start of regular cell division. Either effect could result from a change in the composition of the medium. They are not distinguished from each other in the regressions and are conveniently treated as wholly mortality.

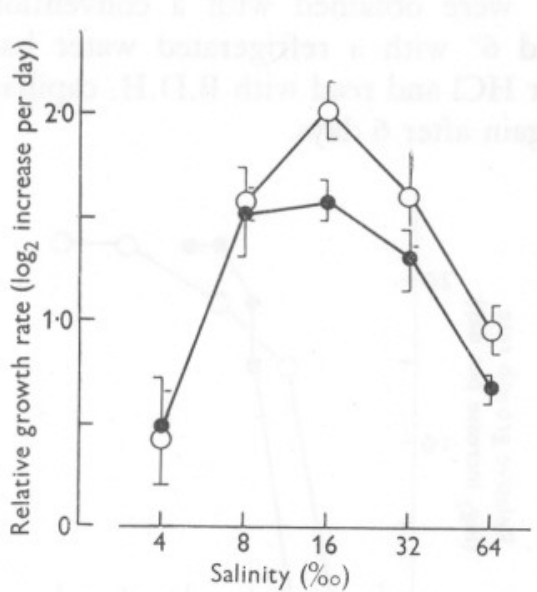

Fig. I

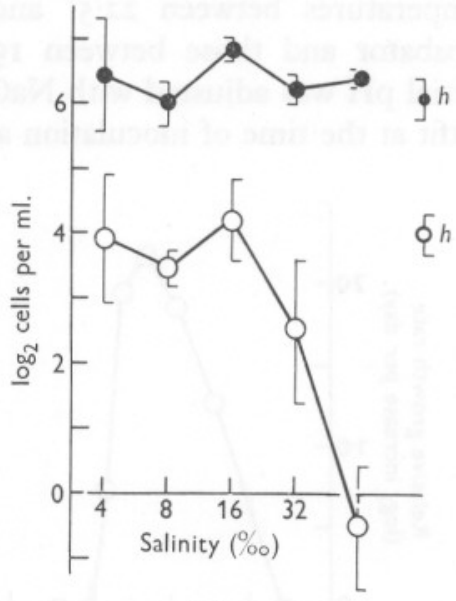

Fig. 2

Fig. I. Relative growth rate $(k)$ as a function of salinity. Open circles, $8 \%$ adapted inoculum; filled circles, $64 \%$ adapted inoculum. $95 \%$ fiducial limits indicated.

Fig. 2. Log 'apparent initial viable count' $(c)$ as a function of salinity. Open circles, $8 \%$ adapted inoculum; filled circles, $64 \%$ adapted inoculum. Log 'initial total count' $(h)$ in each case is shown on the right. $95 \%$ fiducial limits indicated.

The 'initial total count' was obtained by counting sample $0.06 \mathrm{ml}$. aliquots from the inoculum cultures and dividing by 6 (since an inoculum of $0.06 \mathrm{ml}$. was being given to $6.0 \mathrm{ml}$. of culture medium). $h$, the logarithm of this, in the $8 \%$ experiment was 3.95 (fiducial limits \pm 0.30 ), and in the $64 \%$ experiment 6.08 (limits \pm 0.31 ). Fig. 2 shows that $h$ is significantly higher than $c$ only in the case of the two cultures of highest salinity in the $8 \%$ experiment, from which the conclusion is drawn that, while the transfer from a high to low salinity was tolerated without shock, the more extreme cases of reverse transfer were not experienced without harm to the population.

Microscopic observation of the behaviour of cells on transfer confirmed this conclusion and, moreover, showed that the correct interpretation of the 
phenomenon was mortality on transfer and not initial lag. Thus, cells suddenly transferred from 8 to $64 \%$ quickly became lean and angular and apparently dehydrated, shedding their flagella in most cases and all but 2 or $3 \%$ failing to recover; whereas they became swollen and almost completely spherical and sluggish on transfer in the downward direction and they did not shed their flagella but regained shape and activity within the hour.

\section{TEMPERATURE AND $\mathrm{pH}$}

A medium of $\mathrm{I} 6 \%$ salinity was used in the temperature and $\mathrm{pH}$ experiments. Initial $\mathrm{pH}$ in the former was 7.4 and temperature in the latter $22.5^{\circ}$. The temperatures between $22.5^{\circ}$ and $34^{\circ}$ were obtained with a conventional incubator and those between $19^{\circ}$ and $6^{\circ}$ with a refrigerated water bath. Initial $\mathrm{pH}$ was adjusted with $\mathrm{NaOH}$ or $\mathrm{HCl}$ and read with B.D.H. capillator outfit at the time of inoculation and again after 6 days.

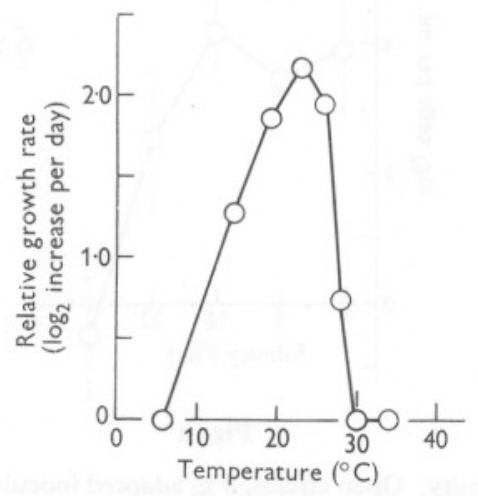

Fig. 3

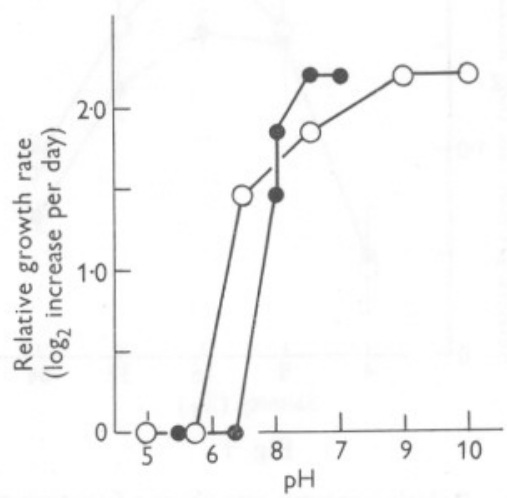

Fig. 4

Fig. 3. Relative growth rate $(k)$ as a function of temperature.

Fig. 4. Relative growth rate $(k)$ as a function of $\mathrm{pH}$. $\mathrm{pH}$ measured: open circles, at start; filled circles, after 6 days.

The results of the two experiments were not subjected to statistical analysis, since the sole parameter required was relative growth rate. They are shown in Figs. 3 and 4 , where relative growth rate is graphed against temperature or $\mathrm{pH}$. There was a temperature optimum of $22^{\circ}-23^{\circ}$, an upper tolerance limit, of $28^{\circ}$, and a $Q_{10}$ of about 2.7 between $10^{\circ}$ and $20^{\circ}$. A pH of 7 or over appears to be suitable.

\section{DISCUSSION}

A maximum division rate of $\mathbf{2} \cdot \mathbf{2}$ per day is higher than is normally met among dinoflagellates and may be correlated with Oxyrrhis's phagotrophic habits. Braarud (I95I) obtained maxima of 0.32 for Exuviaella baltica, 0.55 for 
Amphidinium sp., 0.95 for Peridinium trochoideum; while Braarud \& Rossavik (I95I) obtained 0.55 for Prorocentrum micans, Braarud \& Pappas (I95I) 0.89 for Peridinium triquetrum, and Sweeney (I954) 0.67 for Gymnodinium splendens.

Oxyrrhis is most often encountered in brackish rock pools above the highwater mark and sometimes occurs in water of very high salinity. At the other extreme, it is seldom found in pools whose salinity is lower than $4 \%$, in which respect it differs from many other supra-littoral species which tolerate or even prefer the lower salinities (Droop, I953 $a$, table I0; I955, table I). The optimum salinity for the neritic species studied by Braarud (I95I) ranged from I6 to $20 \%$ with upper and lower toleration limits only slightly narrower than those reported here for Oxyrrhis. It seems that salinity tolerance per se cannot satisfactorily account for the absence of neritic species from supra-littoral pools or of Oxyrrhis from the sea.

The response to sudden changes in salinity is interesting and shows Oxyrrhis well fitted to its habitat, for the salinity of sea-water marks the limit to which a pool can suddenly be raised by sea splash, any further rise being necessarily by evaporation and therefore slow. In south Finland, where this strain originated, this figure is $6 \%$. On the other hand, the reverse change, which is brought about by flooding with rain water, can be quite rapid, especially if mixing is not delayed. It has been observed previously (Hopkins, I938) that the physiological response to changes in salinity of marine Protozoa not possessing a rigid periplast or contractile vacuoles is to contract or to swell. This is due to a temporary unbalance between the osmotic pressure of the internal and external media. Recovery is stated to be due to adjustment by the passage of salts through the membrane, though it might equally be brought about by mobilization or immobilization of carbohydrate reserves of high osmotic pressure. Oxyrrhis certainly has great powers of adjustment, particularly when the change is made gradually. The fact that dehydration is a greater hazard than bursting speaks for the tensile strength of the periplast.

The response to $\mathrm{pH}$ was as expected, for a $\mathrm{pH} 8-9$ is normal for a pool containing Oxyrrhis and one below 7 is seldom encountered in the aerobic layers of supra-littoral pools. The temperature curve is conventional: its peak suggests that Oxyrrhis is a summer organism, which indeed it is, though the high rainfall in this country or ice cover in Finland would in any case keep the pools empty of flagellates during the winter months. The upper laboratory temperature limit of $28^{\circ}$ is often exceeded for short periods in pools containing large populations of Oxyrrhis during the summer; for instance, I obtained midday records of $30^{\circ}$ in Finland (Droop, I953 a). Possibly other more southern races of this species tolerate higher continuous temperatures. 


\section{SUMMARY}

Maximum division rate of the dinoflagellate Oxyrrhis marina Dujardin feeding on Saccharomyces exiguus occurred in cultures of salinity $16 \%$, temperature $22 \cdot 5^{\circ}$ and $\mathrm{pH} 8-\mathrm{IO}$, and was $2 \cdot 2$ per day.

Salinities below $4 \%, \mathrm{pH}$ below 6.5 and continuous temperatures over $28^{\circ}$ were not tolerated.

Sudden extreme changes in salinity were tolerated in the downward but not in the upward direction.

\section{REFERENCES}

BRAarud, T., I95I. Salinity as an ecological factor in marine phytoplankton. Physiol. Plant., Vol. 4, pp. 28-34.

BraARud, T. \& PAPPAS, I., I95I. Experimental studies on the dinoflagellate Peridinium triquetrum (Ehrb.) Lebour. Avh. norske VidenskAkad., 1957, No. 2, pp. I-23.

BRAARUD, T. \& Rossavik, E., I95I. Observations on the marine dinoflagellate Prorocentrum micans Ehrb. in culture. Avh. norske VidenskAkad., I95I, No. I, pp. I-I8.

Droop, M. R., I953a. On the ecology of flagellates from some brackish and freshwater rock-pools of Finland. Acta bot. fenn., Vol. 51, pp. I-52.

— 1953b. Phagotrophy in Oxyrrhis marina Dujardin. Nature, Lond., Vol. 172, p. 250.

— 1955. Some new supra-littoral Protista. F. mar. biol. Ass. U.K., Vol. 34, pp. $233-45$.

HopkIns, D. L., 1938. Adjustment of the marine amoeba, Flabellula mira Schaeffer to changes in the total salt concentration of the outside medium. Biol. Bull., Woods Hole, Vol. 75, p. 337.

SNEDECOR, G. W., 1946. Statistical methods. 4th Edition. Iowa: State College Press.

SWEENEY, B. M., 1954. Gymnodinium splendens, a marine dinoflagellate requiring vitamin $\mathrm{B}_{12}$. Amer. F. Bot., Vol. 4I, pp. 821-24. 